\title{
PANASNYA MATAHARI TERBIT: DERITA RAKYAT SUKABUMI PADA MASA PENDUduKan JePANG 1942-1945
}

\author{
THE HEAT OF THE RISING SUN: \\ SUKABUMI PEOPLE SUFFERING DURING THE JAPANESE OCCUPATION \\ 1942-1945
}

\author{
Sulasman \\ Fakultas Adab dan Humaniora UIN Sunan Gunung Djati Bandung \\ Jln. A. H. Nasution No. 105 Cibiru Bandung \\ e-mail : sulasman14@yahoo.com
}

\begin{abstract}
Abstrak
Tulisan ini bertujuan menggambarkan penderitaan rakyat Sukabumi masa Pendudukan Jepang. Untuk merekonstruksi peristiwa itu digunakan metode sejarah yang meliputi heuristik, kritik, interpretasi, dan historiografi. Hasil penelitian menunjukan bahwa pada awal kedatangannya, tentara Jepang disambut dengan antusias oleh masyarakat Sukabumi. Dengan harapan mereka dapat membebaskan belenggu dari penjajahan Belanda. Banyak tokoh di Sukabumi yang membantu proses pengambilalihan kekuasaan dari tangan Belanda ke Pemerintah Pendudukan Jepang. Ternyata harapan itu tidak sesuai dengan kenyataan. Kebijakan-kebijakannya banyak merugikan bangsa Indonesia. Kebijakannya lebih menekannkan ke arah bagaimana Bangsa Indonesia bisa membantu kepentingannya untuk menjadi imperium baru menggantikan Pemerintah Kolonial Belanda. Pemerintah Pendudukan Jepang telah menggunakan simbol-simbol agama, seperti ulama dan kiai sebagai alat propaganda untuk mendukung program ekonomi perangnya. Ulama dan kiai dididik melalui Program Pendidikan Kader Ulama. Setelah mereka mengikuti pendidikan, diwajibkan menjadi propagandis Pemerintah Pendudukan Jepang dalam program wajib serah padi dan romusha. Kebijakan Pemerintahan Pendudukan Jepang yang melibatkan tokoh tokoh ulama telah menempatkan posisi ulama dan kiai yang tadinya terhormat menjadi tidak terhormat, karena mereka dianggap terlibat dalam peristiwa yang membuat masyarakat Sukabumi mengalami penderitaan. Masyarakat Sukabumi jatuh dalam kemiskinan dan penderitaan ekonomi secara sistematis. Kehidupan masyarakat Sukabumi di bawah Pemerintahan Pendudukan Jepang mengalami penderitaan lahir dan batin.
\end{abstract}

Kata Kunci: Sukabumi, Jepang, Pendudukan.

\begin{abstract}
This text aims to describe the Sukabumi's people sufferings at the time of Japanese occupation in Indonesia. For reconstructing the event, it uses the historical method which includes Heuristics, Critics, Interpretation, and Historiography. The result of this study shows that at the beginning of its arrival, the Japanese Troops was enthusiastically welcomed by the Sukabumi's people. They hoped that the troops can free the people from the Dutch imperialism. There were many figures from Sukabumi who helped the Japanese troops to take over the power from Dutch. In fact, that hope was not realized. The Japanese policies were disadvantageous for Indonesian people. Those policies were emphasized more on how the Indonesian people help the Japanese to
\end{abstract}


become the new imperium which substitute the Dutch Colonial Government. The Japanese troops had used the religious symbols such as the scholars and the Kiai as a tool of propaganda to support their economic war program. The scholars and Kiai were trained through The Scholar Cadre Training Program. After trained, they should become the Japanese propagandists in order to tell and ask people to join the paddy grain sharing program and also romusha program. The Japanese policies that involved the scholar figures had replaced the scholars' and Kiais' position from the honoured one to become the dishonoured one. It was because they were assumed to be responsible for the Sukabumi's people suffering. The Sukabumi's people suffered from the poverty and also suffered from the systematically economic decreasing. The Sukabumi's people life was physically and psychologically suffering under the Japanese occupation.

Keywords: Sukabumi, Japan, Occupation.

\section{A. PENDAHULUAN}

Masa Pendudukan Jepang di Indonesia, merupakan episode tersendiri dan cukup menarik dalam bentangan sejarah Indonesia. Kajian sejarah periode ini banyak ditulis oleh para peneliti diantaranya, Harry J. Benda tahun 1958 menulis The Crescent and the Rising Sun: Indonesian Islam under the Japanese Occupation 1942-1945. George Sanford Kanahele, tahun 1967 menulis The Javanese Occupation of Indonesia : Prelude to Independence. Benedict O'Gorman Anderson, tahun 1988 yang menulis Java in A Time of Revolution, Occuption and Residentence 1942 - 1946 diterjemahkan oleh Jiman Rumbo Revolusi Pemoeda; Pendudukan Jepang dan Perlawanan di Jawa 1944 1946. Aiko Kurasawa tahun 1988 menulis Pendudukan Jepang Dan Perubahan Sosial: Penyerahan Padi Secara Paksa dan Pemberontakan Petani Di Indramayu. Akira Nagazumi tahun 1988 menyunting tulisan tentang Pemberontakan Indonesia Di Masa Pendudukan Jepang. Aiko Kurasawa, tahun 1993 menulis Mobilization and Control, diterjemahkan oleh Hermawan Sulistyo dengan judul Mobilisasi dan Kontrol : Studi tentang Perubahan Sosial di Pedesaan jawa 1942 - 145.

Tulisan mereka kebanyakan melihat peristiwa pendudukan Jepang dalam perspektif nasional, karena gejolak yang terjadi di daerah hanya berperan semacam paduan suara yang mengiringi tema-tema dominan dalam sejarah nasional. Ada beberapa alasan mengapa sejarah dalam perspektif kedaerahan banyak diabaikan diantaranya pertama, dalam menguraikan sejarah yang kompleks orang lebih mengutamakan perspektif nasional. Kedua langkanya informasi mengenai sejarah lokal. Hal ini terjadi juga dengan peristiwa Pendudukan Jepang di Sukabumi.

Secara geografis, Sukabumi merupakan daerah penyangga ibu kota, sehingga letaknya sangat strategis sebagai daerah palang pintu (Slaag Boom) baik itu secara ekonomi, kultural, maupun politik, terutama pada masa revolusi antara tahun 1942-1949.

Menurut L. de Steurs dalam Memories van Overgave saat menjabat sebagai Residen Priangan tanggal 2 Januari 1921, Sukabumi memiliki potensi ekonomi yang cukup tinggi di sektor perkebunan sejak diberlakukannya Undang-Undang Agraria tahun 1870. Dalam Verslag Koffie Onderneming Soekaboemi disebutkan bahwa sejak Sukabumi dibuka sebagai daerah perkebunan baik itu Karet, Teh maupun Kopi, jumlah perkebunan di Sukabumi dari tahun ke tahun semakin meningkat diantaranya adalah perkebunan di daerah Jampang (Verslag der Rubber Exploitatie Maatschappij "Djampang Soekaboemi), Parakansalak (Jaarverslag Cultuur Maatschappij Parakansalak Soekaboemi), Cirohani, Sinagar (Jaarverslag Cultuur Maatschappij Sinagar-Cirohani Soekaboemi), Nagrak (Jaarverslag Cultuur Maatschappij Sinagar-Cirohani Soekaboemi ), Munjul, dan Jayanegara ( Jayanegara Verslag 
over het Naamlooze Vennonschap Assam
thee Onderneming Djajanegara Soekaboemi ). Perkebunan di Priangan termasuk di Sukabumi kebanyakan dimiliki oleh orang Belanda yang biasa di sebut dengan "Preangers Planters" (Kunto, 1984: 21 ). Diantara pemilik perkebunan atau "Toean Keboen" yang terkenal di Sukabumi adalah Andries de Wilde pemilik perkebunan di daerah Cimalati dan daerah Gunung Parang serta keluarga "The Hole" yang terdiri dari Willem van der Hucht, Adriaan W. Hole, Albert Hole, dan Eduard Kerkhoven pemilik perkebunan Parakansalak, Sinagar, Munjul ( Lubis, 1998: 117, dan Haasse, 1934: 65). Sukabumi merupakan salah satu daerah perkebunan di Priangan yang menjadi andalan finansial bagi Pemerintah Kolonial Hindia Belanda guna menutupi kebangkrutan finansial akibat "Perang $J a w a$ " antara Belanda melawan Pangeran Dipenogoro ( Kunto, 1991: 21).

Salah satu tujuan Jepang menguasai daerah Sukabumi, karena daerah tersebut merupakan daerah perkebunan yang sangat potensial secara ekonomi ( Abdulqohar, wawancara 12 Maret 2004 ). Pada masa pendudukan Jepang, perkebunan mempunyai peranan yang sangat penting untuk digunakan sebagai penunjang program ekonomi perangnya ( Kurasawa, 1993: 49-53 ). Begitu juga dengan perkebunan di Sukabumi, Pemerintah Pendudukan Jepang menggukan hasil perkebunan dari daerah Jampang Parakansalak, Cirohani, Sinagar, Munjul, Jayanegara untuk membiayai program ekonomi perangnya.

Sukabumi masa pendudukan Jepang cukup menarik untuk ditulis. Karena pada masa itu, tragedi kemanusiaan yang cukup memilukan di daerah Sukabumi tidak akan terlupakan sepanjang sejarah. Kemiskinan sistematis akibat kebijakan-kebijakan Pemerintah Pendudukan Jepang telah menyebabkan masyarakat Sukabumi jatuh dalam kehidupan di luar batas kemanusiaan.

\section{HASIL DAN PEMBAHASAN}

1. Serbuan Tentara Jepang ke Jawa Barat

Untuk menguasai wilayah Jawa Barat, pasukan Jepang yang mendarat di Desa Bojonegara Teluk Banten terdiri dari dua kolone bala tentara terus bergerak merambah ke arah Timur. Kemudian pasukan ini dibagi menjadi dua. Pasukan pertama bergerak menyusuri jalur Serang lewat Balaraja menuju Tanggerang, kemudian masuk ke Batavia. Sementara itu pasukan kedua bergerak menyusuri jalur Serang lewat Rangkasbitung menuju Bogor. Pada tanggal 5 Maret 1942 bala tentara Jepang telah berhasil merebut dan menduduki Leuwi Liang Bogor.

Dalam waktu yang bersamaan, Mayor Jenderal Schiling dengan Pasukan Hindia Belandanya meninggalkan wilayah kekuasaan militernya di Batavia dan mundur ke Bandung. Di tengah perjalanan dihadang oleh bala tentara Jepang pimpinan Kolonel Nasu yang telah berhasil menguasai Bogor. Ketika pasukan Mayor Jenderal Schiling akan menghindar ke arah Barat, disana sudah dihadang oleh pasukan bala tentara Jepang lainnya yang bergerak dari arah Karawang. Dalam keadaan babak belur dan kepayahan, sisa pasukan Mayor Jenderal Schiling baru tiba di Bandung tanggal 6 Maret 1942.

Dalam usahanya untuk merebut kota Bandung, pasukan yang telah mendarat di Pantai Eretan Indramayu dengan kekuatan 5000 personil pimpinan Kolonel Toshinori Shoji, bergerak ke arah Barat Cirebon, sehingga pada hari yang sama pasukan yang dipimpin Kolonel Shoji dapat menduduki Subang dan menguasai Pangkalan Udara Kalijati Subang yang jaraknya hanya sekitar 40 Kilometer dari Bandung (Asia Raja, 28 Mei 1942 ).

Setelah menguasai Subang, tentara Jepang pimpinan Kolonel Shoji terus bergerak dengan tujuan merebut kota Bandung. Langkah mereka dimulai dengan merebut daerah pertahanan 
tentara Hindia Belanda di Ciater. Sementara itu tentara Hindia Belanda mundur ke Lembang sebagai daerah pertahanannya yang terakhir. Akan tetapi Lembang pun tidak lama dipertahankan oleh Tentara Hindia Belanda, karena tentara Jepang berhasil menguasainya tepat pada tanggal 7 Maret 1942 (Poesponegoro, 1984:3-4).

Operasi kilat Detasemen Shoji, membuat kritis posisi tentara Hindia Belanda ( KNIL ) dalam pertempuran di Jawa Barat. Untuk mengatasi hal itu, pada tanggal 6 Maret 1942 Panglima KNIL Letnan Jenderal H. Ter Poorten memerintahkan Panglima KNIL di Jawa Barat Mayor Jenderal J. J. Presman untuk tidak mengadakan pertempuran di Bandung, karena kota Bandung merupakan daerah yang penuh sesak dengan penduduk sipil yang kebanyakan orang-orang Belanda dan Eropa lainnya, sehingga perlu dicegah terjadinya pertempuran di kota tersebut.

Setelah Jepang menguasai Lembang, Panglima Angkatan Darat Belanda Letnan Jenderal H. Ter Poorten memerintahkan Mayor Jenderal J. J. Presman Komandan Pertahanan Militer Bandung supaya berunding dengan pihak bala tentara Jepang. Mayor Jenderal Pressman pada tanggal 7 Maret 1942 mengirimkan utusannya ke Lembang untuk menemui Kolonel Shoji dan mengajukan perundingan gencatan senjata.

Setelah menerima utusan Belanda, Kolonel Shoji menyatakan kesediaannya kepada Mayor Jenderal Pressman dan meminta untuk bertemu di Gedung Isola Bandung pada tanggal 8 Maret 1942 pukul 8,30. Kolonel Shoji menghubungi Panglima Tentara Keenam belas Jenderal Imamura dan menyampaikan persoalan mengenai gencatan senjata kepadanya. Kemudian Jenderal Imamura memerintahkan Kolonel Shoji untuk menghubungi Gubernur Jenderal Tjarda van Starkenborgh Stachouwer untuk segera mengadakan perundingan dengan pihak Jepang.

Terhadap tuntutan yang diajukan oleh, Panglima Angkatan Darat Hindia Belanda Letnan Jenderal H, Ter Poorten meminta Gubernur Jenderal Tjarda van Starkenborgh Stachouwer untuk menolak permintaan Jepang. Akibat penolakan yang dilakukan oleh, Gubernur Jenderal Tjarda van Starkenborgh Stachouwer terhadap tuntutannya, maka Panglima Tentara Keenam belas Jenderal Hitoshi Imamura bereaksi keras dengan mengeluarkan ultimatum bahwa jika pada tanggal 8 Maret 1942 pukul 10.00 pagi para pembesar Belanda belum juga berangkat ke Kalijati Subang, maka kota Bandung akan dibombardir dihancur leburkan. Selain itu Jenderal Imamura mengajukan tuntutan agar Gubernur Jenderal Belanda turut serta dalam perundingan di Kalijati Subang. Dia mengatakan bahwa jika tuntutannya itu dilanggar oleh pihak Belanda, pemboman atas kota Bandung dari udara akan segera dilaksanakan. Ancaman Jepang disertai bukti dengan dilakukan unjuk kekuatan Angkatan Udara Jepang diatas kota Bandung, Kapal armada pembon Angkatan Udara Jepang meraung-raung diatas kota Bandung. Untuk menguatkan ancamannya dilakukan uji coba dengan dijatuhkannya bom di perempatan Regentsweg Dalem Kaum yang mengakibatkan jatuhnya banyak korban yang tewas. Atas kejadian itu maka Gubernur Jenderal Tjarda van Starkenborgh Stachouver maupun Panglima Tentara Hindia Belanda Letnan Jenderal H. Ter Poorten serta beberapa pejabat tinggi militer dan seorang penerjemah pergi ke Kalijati Subang. Di Subang mereka berhadapan dengan Panglima Tentara Keenambelas Jenderal Imamura yang datang dari Batavia (Notosusanto, 1979: 27). Hasil perundingan adalah penyerahan tanpa syarat Angkatan Perang Hindia Belanda kepada Jepang. Dengan penyerahan tanpa syarat oleh Letnan Jenderal H. Ter 
Poorten Panglima Angkatan Perang

Hindia Belanda atas nama Angkatan Perang Serikat di Indonesia kepada tentara ekspedisi Jepang dibawah pimpinan Letnan Jederal Hitoshi Imamura, maka sejak tanggal 8 Maret 1942 berakhirlah pemerintahan Hindia Belanda di Indonesia.

Dalam waktu yang cukup singkat, dengan gerakan kilat bala tentara Jepang telah menguasai daerah-daerah strategis, terutama daerah yang dapat menopang sektor perekonomiannya. Sasaran Jepang berikutnya setelah mengambil alih kekuasaan politik adalah mengambilalih kekuasaan ekonomi. Daerah-daerah perkebunan di wilayah Priangan seperti Sukabumi, menjadi target untuk dapat dikuasainya. Hal ini disebabkan karena hasil perkebunan dapat menunjang Pemerintah Pendudukan Jepang pada program ekonomi perangnya.

\section{Masuknya Tentara Jepang ke Sukabumi}

Bala Tentara Jepang masuk ke wilayah Sukabumi melalui Bogor. Mereka berasal dari pasukan tentara pimpinan Kolonel Nasu. Dalam waktu yang relatif singkat, tentara Jepang telah menguasi daerah-daerah perkebunan di Sukabumi seperti perkebunan Parakansalak, Nagrak, Cirohani, Cimelati, Salabintana, maupun perkebunan-perkebunan lainnya (Halim, wawancara 10 Mei 2004). Masyarakat Sukabumi saat itu banyak yang merasa heran, karena tiba- tiba banyak "orangorang kate" yang berkeliaran di kampung-kampung. Mereka sering menyapa penduduk dengan ramah, sehingga membuat masyarakat kampung tertarik dengan keramahannya, tidak nampak watak kasar dan keras seperti yang ditampilkan kemudian hari.

Para pemimpin lokal di Sukabumi pada umumnya menyambut kedatangan Jepang dengan suka cita dengan harapan bahwa Jepang dapat membebaskan bangsa Indonesia dari belenggu kolonial Belanda. Seperti yang dilakukan oleh
Kiai Haji Ahmad Sanoesi dari Pondok Pesantren Gunung Puyuh. Ia menyambut kedatangan Jepang secara baik, bahkan bersedia bekerja sama dengannya. Sebagai orang yang berwawasan luas sekaligus sebagai pemimpin sosial yang sangat dihormati, Kiai Haji Ahmad Sanoesi melihat bahwa kerja sama dengan Jepang sebagai cara dalam menghalau penjajah Belanda. Kerja sama yang dilakukannya hanya merupakan strategis perjuangan semata. Hal ini ditunjukan oleh Ajengan Gunung Puyuh pada saat tentara Jepang datang ke Sukabumi dari arah Bandung. Ia mengerahkan segenap anggotanya yang tergabung dalam $A l$ Ittihadijjatoel Islamijjah ( AII ) maupun Barisan Islam Indonesia (BII) untuk menunjukkan kantong-kantong pertahanan serdadu Belanda. Atas bantuan tersebut, maka dalam waktu yang relatif singkat Jepang dapat menguasai keadaan ( Abdulqohar, wawancara 12 Maret 2004 ).

Setelah Jepang berhasil menduduki Sukabumi, ke kota itu datang utusan Jepang, yaitu Haji Abdul Muniam Inada untuk menemui Kiai Haji Ahmad Sanoesi. Ia mengucapkan terima kasih kepada Ajengan Gunung Puyuh yang telah membantu Jepang menghadapi Belanda di Sukabumi. Untuk selanjutnya pihak Jepang terus melakukan pendekatan guna melakukan kerja sama kepada Kiai Haji Ahmad Sanoesi, dengan harapan Ajengan Gunung Puyuh itu bisa membantu Jepang dalam melaksanakan program-programnya selama masa Pemerintahan Pendudukan Jepang di Indonesia, khususnya di daerah Sukabumi. Sebagai imbalan dari kerja sama yang dilakukan oleh tokoh Sukabumi itu, maka dia diberikan kemudahan-kemudahan dalam segala macam urusan bahkan sebagai tanda terima kasih, pihak Jepang mengangkat Kiai Haji Ahmad Sanoesi dalam posisi birokrasi pemerintahan yaitu sebagai Fuku Shuchokan wilayah Bogor (Mawardi, 1985:98). 
Selain Kiai Haji Ahmad Sanoesi, pemerintahan Pendudukan Jepang juga mengangkat orang Sukabumi lainnya yaitu Mr. Syamsudin salah seorang tokoh AII pimpinan Ajengan Gunung Puyuh untuk menduduki jabatan sebagai ketua Gerakan Tiga A, dengan tugas mengorganisir kaum intelektual, kelompok-kelompok agama baik Islam, Kristen maupun lainnya baik itu Priyayi ataupun pejabat pemerintah ( Sulasman, $2008 ; 156$ ).

Ketika Ir. Soekarno yang sangat anti kolonialis dan imperialis mengetahui sikap Kiai Haji Ahmad Sanoesi yang melakukan kerja sama dengan Jepang, ia mempertanyakannya kepada pemimpin Pondok Pesantren Gunung Puyuh mengenai hal tersebut ketika sedang menjalani perawatan oleh Dr. Abu Hanifah di Rumah Sakit Sint Lidwina. Berkali-kali Ir. Soekarno mengunjungi Pondok Pesantren Gunung Puyuh untuk berdialog dengan Kiai Haji Ahmad Sanoesi. Dalam pertemuannya dengan Ir. Soekarno, Kiai Haji Ahmad Sanoesi menjelaskan, bahwa Jepang berstatus penjajah baru. Mereka orang Timur datang di Indonesia menghadapi dua lawan, yaitu bangsa Indonesia dan penjajah Belanda yang menjadi lawan sekutunya. Dengan kedok kerja sama, tenaga dan keterampilannya bisa dimanfaatkan, pertama untuk mengusir Belanda, kedua mereka bisa diminta keahliannya untuk mendidik penduduk pribumi dalam bidang militer. Karena Bangsa Jepang mempunyai keunggulan dalam bidang militer seperti yang telah disaksikannya bahwa dalam tempo yang relatif singkat Jepang telah berhasil menguasai kawasan Asia Tenggara. Saat itupun disampaikan pula oleh Kiai Haji Ahmad Sanoesi kepada Ir. Soekarno, Jepang pernah menyampaikan kepadanya bahwa perlu adanya kerja sama dengan bangsa Indonesia dalam rangka Perang Asia Timur Raya. Menurut pandangan Kiai Haji Ahmad Sanoesi, kesempatan tersebut jangan sampai dilewatkan.
Rupanya pemikiran Ajengan Gunung Puyuh dapat diterima oleh Ir. Soekarno dalam menghadapi Jepang. Saat itu Ir. Soekarno mengatakan bahwa hal tersebut akan didiskusikan dengan tokoh- tokoh perjuangan lainnya. Sikap Kiai Haji Ahmad Sanoesi banyak di ikuti oleh tokoh-tokoh lainnya di Sukabumi terutama dari kalangan Pondok Pesantren seperti Kiai Haji Mohammad Hasan Basri dari Pondok Pesantren Babakan Cicurug, Kiai Haji Mohammad Basoeni dari Pondok Pesantren Cipoho Sukabumi ( Sulasman, 2008; 90 ).

\section{Tindakan Pemerintah Pendudukan Jepang}

a. Kiai, Ulama, dan Propaganda Jepang

Untuk dapat menarik simpati umat

Islam Indonesia dalam rangka menjalankan politiknya di negara bekas jajahan Belanda, Pemerintah Pendudukan Jepang memberikan peran yang cukup besar dalam peran sosial dan politik yang penting terhadap para pemimpin Islam.

Ketika tentara Jepang menduduki Indonesia mulai awal tahun 1942, harapan akan kerja sama dari kaum Muslim menjadi sebuah kebutuhan yang mendesak, dan upaya Jepang itu memperoleh makna yang lebih penting. Adapun sikap dasar Jepang terhadap Islam diatur dalam "Prinsip-prinsip Mengenai Pemerintahan Militer di Wilayah Pendudukan " yang dikeluarkan pada tanggal 14 Maret 1942 ( Kurasawa, 1993: 72 ).

Menurut Kurasawa (1993), kebijakan Jepang terhadap Islam selalu merupakan bagian yang tak terpisahkan dari "operasi propaganda dan penjinakan ". Mereka memandang agama sebagai sebuah alat penting untuk memanipulasi pikiran rakyat, dan menaruh perhatian khususnya terhadap peran para pemimpin Islam. Harapan yang sangat besar dicurahkan pada guruguru Islam setempat terutama di kalangan Kiai yang sehari-hari berhubungan langsung dengan rakyat, sehingga mereka 
dapat menjadi pembantu yang diinginkan Jepang dalam menjalankan indoktrinasi politik atas penduduk pribumi.

Untuk merebut perhatian Umat Islam Indonesia, pemerintah Militer Jepang menunjukan sikap yang bersahabat terhadap alim-ulama dan berusaha menggalang kerja sama dengan mereka. Jepang ingin mengambil keuntungan dari kepopuleran dan gengsi para alim ulama. Menurut Kurasawa (1993: 273-275), ada tiga tindakan sangat penting yang dilakukan Jepang untuk memanfaatkan alim-ulama dalam kebijakan propaganda dan mobilisasi massa. (1)Didirikannya sebuah organisasi Muslim, yaitu Masyumi. (2) Dibentuknya seksi urusan keagamaan (Shumuka) di setiap pemerintahan karesidenan. Adapun kewajiban utama seksi ini adalah melakukan kontrol atas alim-ulama setempat dan memobilisasi mereka demi tujuan-tujuan propaganda.

Diselenggarakan program " Latihan Alim Ulama ", yang dapat ditafsirkan sebagai usaha untuk membuat alim ulama yang berpengaruh sebagai propagandis yang pro Jepang.

Program Latihan Alim Ulama sangat dirasakan pengaruhnya di dalam masyarakat, sehingga terjadi perubahan dalam tatanan sosial terutama masyarakat pedesaan (Abdulqohar, wawancara 12 Maret 2004 ). Ini disebabkan karena terjadinya perubahan peran yang dimainkan oleh Kiai yang tadinya berperan sebagai pemimpin sosial keagamaan yang kharismatik serta dihormati dan sekaligus pengayom masyarakat pedesaan, berubah peran menjadi seorang propagandis Pemerintahan Militer Jepang, yang bertugas untuk meyakinkan kepada masyarakat bahwa betapa pentingnya program-program pemerintahan Militer Jepang seperti "wajib serah padi" dan "romusha" untuk membangun negara meskipun pada pelaksanaannya telah menyengsarakan rakyat. Saat itu, pandangan masyarakat terhadap Kiai dan alim ulama lainnya, terutama yang menjadi propagandis Jepang tidak sesakral seperti sebelumnya, bahkan tidak sedikit masyarakat memberikan julukan-julukan yang kurang baik pada mereka diantaranya menjuluki mereka sebagai Kiai Kuintal, Kiai Romusha dan sebagainya, sebagaimana yang ceritakan oleh beberapa informan dari wilayah Sukabumi terutama daerah Parungkuda, Cicurug dan Cidahu.

Selama masa Pemerintahan Militer Jepang, kursus dilaksanakan sebanyak 17 kali. Jumlah alim ulama yang telah mengikuti latihan ini diperkirakan lebih dari seribu orang. Setelah kursus selesai, kepada para alim ulama yang menjadi peserta oleh pemerintah Militer Jepang melalui Shumubu diberi diploma dan mereka kembali ke desa asalnya. Pada saat kembali ke desanya masing-masing setelah mengikuti kursus alim-ulama, mereka banyak yang memerankan peran baru sebagai propagandis pemerintah, terutama dalam pelaksanaan program wajib serah padi dan romusha. Ijazah yang mereka miliki tidak hanya berlaku semata-mata sebagai tanda telah menyelesaikan latihan, tetapi lebih jauh digunakan sebagai pengenal kalau mereka sedang menjalankan propaganda, dan ijazah ini dianggap sebagai tanda bahwa pemiliknya adalah seorang kooperator yang setia pada Jepang.

Pemerintahan Militer Jepang berkeinginan bahwa Kiai yang telah dididik melalui pelatihan ulama sebagai propagandis untuk berkotbah dan menyebarkan keinginan Jepang di kalangan rakyat. Saat itu Jepang berusaha mempengaruhi pandangan rakyat melalui seringnya berhubungan dengan Kiai dari daerah ketika sedang dalam latihan tersebut. Jepang ingin memanfaatkan Kiai sebagai perantara komunikasi antar pemerintah dan rakyat. Kalau pelatihan itu tidak cukup berhasil mengubah peserta pelatihan menjadi pendukung perjuangan Jepang, paling tidak pelatihan itu bermanfaat untuk menjaga agar 
mereka jangan bersikap anti Jepang ( Kurasawa, 1993: 317).

Penguasa Jepang tidak pernah melewatkan kesempatan untuk memanfaatkan acara keagamaan apapun demi maksud propagandanya. Mereka mengijinkan ulama berkhotbah, dan sebagai imbalannya diminta untuk merujuk pada soal-soal politik pada khutbahnya. Misalnya selama bulan puasa 1944 pemerintah mengatur program radio selama 15 menit setiap hari. Dalam program tersebut ulama dari setiap karesidenan setiap hari bergiliran untuk menyampaikan khotbah mereka, dan pemerintah tidak pernah melewatkan kesempatan untuk meminta mereka merujuk pada soal-soal, seperti penebalan keyakinan akan kemenangan akhir Jepang, serta meningkatkan semangat kerja.

Ulama juga dimanfaatkan untuk menghimbau perasaan rakyat kalau terjadi situasi atau kejadian yang mungkin kurang menyenangkan, Kiai mempunyai tugas untuk menjelaskan kepada rakyat mengenai kebijakan pemerintah yang isinya tidak menyenangkan, dan mendorong agar kebijakan itu diterima. Merekalah yang harus mendorong kalau rakyat menghindari romusha, atau terbukti tidak mau menyerahkan padi, atau menolak menjadi Heiho dan Sukarelawan (Abdulqohar, wawancara tanggal 12 Maret 2004 ).

Salah satu tugas ulama yang sangat penting adalah menenangkan romusha. Kiai ditugaskan memberikan ceramah didepan calon-calon romusha yang ada didaerahnya menjelang keberangkatan mereka ke tempat-tempat kerjanya, dan mendorong mereka dengan menekankan betapa pentingnya mereka. Seperti yang pernah terjadi di Banten Selatan, tujuh orang guru agama pernah dikirim ke tempat ribuan romusha bekerja sebagai buruh paksa, untuk mendorong supaya mereka giat bekerja ( Soeara Moeslimin
Volume II Nomor 17 tanggal 1 September 1944 ).

Peranan Kiai sebagai alat propaganda Jepang mendapatkan reaksi yang beragam dari masyarakat. Banyak julukan-julukan bernada sinis yang diberikan pada para Kiai yang menjadi propagandis Jepang, diantaranya ada yang disebut Kiai mata-mata kempetai, seperti yang diberikan kepada Kiai Harun dari Banyuwangi, atau Kiai kuintal seperti yang diberikan kepada Kiai Abas dari Pondok Pesantren Buntet (Kurasawa, 1993; 318-320).

\section{b. Wajib Serah Padi}

Untuk menunjang program ekonomi perangnya, Pemerintahan Pendudukan Jepang melakukan kontrol yang sangat ketat terhadap hasil produksi secara efektif terutama terhadap produksi pertanian. Salah satu programnya adalah "wajib serah padi" yang mengharuskan petani untuk menyerahkan sebagian produksi pertanian mereka, yaitu padi sebagai bahan makanan pokok terpenting kepada pemerintah dengan harga murah.

Pemerintahan Jepang, menetapkan Jawa sebagai pemasok beras untuk pulau di luar Jawa, Malaya-Inggris, dan Singapura serta untuk medan pertempuran di Pasifik Selatan. Meskipun kapasitas produksi beras di Jawa tidak sebesar Siam, Jawa merupakan salah satu dari sedikit daerah penghasil beras di kepulauan Indonesia. Pulau Jawa saat itu dituntut untuk menghasilkan beras sebanyak 50.000 ton, dan 30.000 ton jagung (Soeara Asia, April 1944).

Lima bulan setelah berkuasa, Pemerintah Militer Jepang (Gunseikanbu) mengambil langkahlangkah pertama ke arah perolehan bahan pangan secara lebih sistematis. Sebuah organisasi untuk mengelola bahan pangan yang disebut Shokuryo Kanri Zimusho (Kantor Pengelolaan Makanan) yang di singkat SKZ dibentuk di bawah Departemen Perindustrian 
Gunseikanbu. Organisasi ini bertanggung jawab atas pengenalan seluruh proses pembelian dan distribusi beras di bawah monopoli negara. Organisasi ini menetapkan jumlah padi yang harus dibeli pemerintah dan menetapkan harga beras resmi, juga merancang program terperinci untuk distribusi beras bagi penduduk perkotaan.

Setelah diresmikannya organisasi Shokuryo Kanri Zimusho (S.K.Z), pada bulan Agustus 1942 dimulai pembelian beras dalam skala besar oleh pemerintah dengan cara sistematis. S. K. Z mengalami kesulitan dalam memperoleh beras yang cukup. Hal ini disebabkan karena jarang terdapat cadangan beras di penggilingan karena mereka tidak membeli beras dalam jumlah yang cukup besar pada saat musim panen terakhir. Untuk hal tersebut, S.K.Z dengan modal yang cukup besar, mereka memerintahkan penggilingan untuk membeli padi yang lebih banyak dari petani. Tetapi sangat sedikit padi yang tersisa di tangan petani karena musim panen besar saat itu sudah lewat.

Kebijakan Pemerintah Pendudukan Jepang mengenai padi mengalami perubahan. Mulai awal tahun beras yang baru yaitu April 1943, pasar beras bebas sama sekali dilarang, dan petani diharuskan untuk menyerahkan sejumlah tertentu dari hasil panen mereka kepada pemerintah. Padi yang diserahkan akan digiling dan didistribusikan melalui tangan pemerintah. Penggilingan dan pedagang beras yang ada tidak lagi diizinkan untuk beroperasi atas prakarsa mereka sendiri, tetapi hanya boleh beroperasi sebagai agen-agen teknis, yang diizinkan Shokuryo Kanri Zimusho (S.K.Z) mengolah atau menangani beras dengan imbalan tertentu.

Kebijakan wajib serah padi dilaksanakan dengan cara sebagai berikut: Pertama, atas permintaan dari berbagai sektor, Shokuryo Kanri Zimusho (S.K.Z) menetapkan jumlah beras keseluruhan yang diperlukan oleh pasukan Jepang, ekspor ke luar Jawa, dan konsumsi lokal. Kemudian mereka mengalokasikan kuota bagi setiap karesidenan menurut kapasitasnya, selanjutnya kuota bagi setiap karesidenan dibagi lagi diantara kabupaten-kabupaten yang dibawahinya. Lalu dengan cara yang sama, masing-masing kabupaten menetapkan alokasi bagi kewedanaan, kewedanaan untuk kecamatan, dan akhirnya kecamatan untuk desa.

Penyerahan padi didelegasikan kepada dan diawasi oleh kucho. Dengan demikian, tanggung jawab penyerahan padi berada di tangan kucho. Kemudian kucho biasanya menunjuk seseorang untuk membantunya mengelola dan menjalankan kewajiban ini. Dengan demikian ia membangun pangawasan yang sangat ketat atas produksi dari penduduk desa. Untuk menjalankan tugasnya, biasanya menjelang panen kucho mengirimkan orang-orangnya untuk menaksir hasil setiap sawah, dan jika seseorang ingin memulai memanen sawahnya, ia harus melapor kepada kucho sehingga bisa mengirim orang untuk mengawasi panen tersebut. Panen di desa-desa jarang dilakukan secara diam-diam, karena saat itu panen masih dilakukan secara tradisional. Dalam panen tradisional seperti yang dilakukan di daerah Sukabumi, khususnya di wilayah Cicurug yang meliputi Parungkuda, Cicurug, Cidahu dan daerah sekitarnya, biasanya setiap orang bergabung untuk menjadi buruh pemanen, dan mereka yang ikut serta diberi imbalan padi yang disebut dengan bawon (Nengsih, wawancara tanggal 25 Agustus 2004).

Setelah menerima padi dari petani, orang yang bertanggungjawab terhadap penyerahan padi melapor kepada kucho. Jika padi tidak memenuhi jatah kuota yang diberikan kepada desa itu, maka diakhir musim panen kucho harus bertanggung jawab. Sebenarnya setiap penyerahan padi selalu dibawah permintaan. Untuk memenuhi standar 
permintaan, maka penguasa desa melakukan penggeladahan kepada para petani. Penggeladahan ini dilakukan kucho dengan menunjuk tim penyelidik yang anggotanya terdiri dari kucho, pamong desa, pembeli padi yang ditunjuk, dan anggota keibodan. Tim penyelidik ini bertugas untuk menggeladah gudang dan rumah-rumah petani. Penggeladahan tersebut sebenarnya merupakan tindakan informal yang dilakukan atas perintah pribadi pangreh praja atau penguasa desa, dan bukan merupakan sanksi legal. Jika seorang petani ditemukan menyimpan padi " berlebihan ", surplus ini di sita.

Atas tindakan pangreh praja atau
kepala desa untuk melakukan penyelidikan terhadap para petani, pada gilirannya petani juga berusaha untuk menghindari penyitaan. Oleh karena itu, maka para ibu isteri petani dengan dibantu anak-anaknya sibuk untuk menyelamatkan padinya dari penyitaan dengan cara menyembunyikan padi ditempat tempat tertentu, seperti bantal atau kasur, di bawah tempat tidur, dan langit-langit rumah.

Disamping menyembunyikan padi, para petani untuk menghindari penggeladahan dari para penyelidik adalah dengan cara menumbuk padi di rumah yang dilakukan oleh para isteri dan anak-anak perempuannya, kemudian hasilnya dijual di pasar gelap (Engkom, wawancara tanggal 7 Juli 2004). Hal ini disebabkan harga di pasar gelap jauh lebih tinggi dari pada harga penjualan kepada pemerintah. Seperti yang diungkapkan oleh To'I (wawancara tanggal 6 Juni 2004), seorang petani dari desa Pondok Kaso Tengah kecamatan Cidahu Sukabumi dan Idim (wawancara tanggal 8 Juli 2004 ) seorang petani dari Desa Cipanengah kecamatan Parungkuda Sukabumi mengungkapkan bahwa mereka menyisihkan dari hasil panennya yang tidak disetorkan kepada kepala desa, dan untuk menghindari penggeladahan yang dilakukan oleh keibodan mereka jadikan beras dan menjualnya ke Pasar Cicurug yang jaraknya sekitar 12 Kilometer dari desa mereka. Selain ke pasar Cicurug, juga dijual ke pasar Cibadak bahkan ke Bogor.

Para petani di pedesaan Sukabumi seperti di wilayah Cicurug dan Cidahu dari desa Cibodas, desa Pondok Kaso, dan desa Cidahu biasanya setelah panen, mereka membayar utang-utangnya bekas kebutuhannya selama musim tanam. Sistem ini di wilayah itu disebut dengan "barnen" (bubar panen) atau "yarnen" (bayar panen). Oleh karena itu, para petani hanya mempunyai sedikit padi yang berada di tangan mereka.

Bagi masyarakat Sukabumi, kususnya para petani di pedesaan pelaksanaan wajib serah padi merupakan masa yang sulit. Hal ini disebabkan karena mereka selain menanggung beban hutang tradisionalnya, dia juga harus mernyerahkan 30 sampai $50 \%$ dari hasil produksi mereka kepada pemerintah.

Kehidupan petani di pedesaan Sukabumi sangat menderita terutama dirasakan oleh para kaum ibu. Hal ini disebabkan mereka susah untuk membeli beras di pasaran karena kesempatan untuk membeli beras di pasar ditiadakan atau dihilangkan. Untuk menutupi kekurangan beras, pemerintah mendorong rakyat supaya makan berbagai makanan pelengkap dengan cara memperkenalkan resep-resep barunya khususnya kepada para wanita. Resepresep tadi oleh para propagandis umumnya disebut dengan "menu perjuangan". Salah satu resep yang terkenal adalah bubur campuran yang disebut dengan "bubur perjuangan" yang terbuat dari campuran ubi, singkong, dan katul. Selain itu, dikenalkan pula Roti Asia yang terbuat dari tepung ketela dan tepung kedelai. Kebanyakan menu yang dianjurkan oleh pemerintah saat itu terdiri dari singkong, jagung, kedelai, dan komoditi semacam itu. Akan tetapi harga-harga bahan makanan tersebut juga 
meningkat di pasar bebas karena menurunnya panen dan meningkatnya permintaan. Bahkan karena susahnya bahan-bahan makanan,

Berbagai bahan makanan yang layak dimakan sudah tidak bisa didapat, maka berbagai jenis bahan yang sebelumnya tidak pernah dimakan, dimanfaatkan seperti bonggol dan batang pisang, batang pepaya dan daun singkong (Sanukri, wawancara 20 Juli 2004). Daun pepaya dimasak dengan tanah supaya rasa pahitnya hilang. Pada saat itu, pemerintah menganjurkan rakyat supaya makan bekicot sebagai pengganti protein.

Sekalipun ada gagasan untuk mengganti menu, gizi masyarakat semakin buruk terutama di masyarakat pedesaan, banyak penduduk desa yang mati lemas karena kelaparan. Hal ini mengakibatkan di desa-desa di wilayah Cicurug dan Cidahu banyak "siring". Siring adalah orang yang datang ke suatu kampung untuk minta-minta atau nyapir makanan. Ia tidak kuat lagi untuk melanjutkan perjalanannya karena kelaparan, sehingga hampir mati karena lemas. Oleh penduduk kampung yang mengetahui hal itu, orang tersebut segera dikirimkan ke kampung tetangganya supaya orang tadi tidak mati di daerahnya, karena jangankan mengurus kematian orang lain, masyarakat setempat pun sedang dalam keadaan susah dan kelaparan. Tidak lama kemudian siring oleh penduduk setempat dipindahkan lagi ke kampung lainnya, begitu terus secara estafet sampai akhirnya orang tersebut mati. Tidak jarang malah orang yang hampir mati lemas karena kelaparan atau siring itu oleh penduduk yang dikubur hiduphidup daripada merepotkan ( Sanukri, wawancara tanggal 20 Juli 2004 ) .

Bagi penduduk pedesaan di wilayah Sukabumi khususnya wilayah Cicurug, Parungkuda, dan Cidahu, hidup di bawah pemerintah pendudukan Jepang merupakan mimpi buruk, mereka hidup dalam derita kemiskinan yang tiada tara. Dimana- mana terjadi kelaparan, banyak para penduduk tidak bisa lagi makan nasi. Karena sangat miskinnya saat itu mereka paling bagus makan nasi yang direumbeuy atau dicampur dengan buah pisang, bahkan tidak sedikit penduduk yang makan bonggol pisang. Ibu-ibu setiap pagi sambil menggendong anaknya yang kelaparan dengan ditemani anak yang lainnya pergi ke kebun atau ke kontrak untuk mencari hui ( ubi ), atau pisang buat campur nasi. Kalau tidak mendapatkannya, mereka terpaksa mengambil bonggol pisang. Saat itu beban yang dirasakan kaum wanita terutama ibu-ibu rumah tangga semakin bertambah, selain harus mengurus anak, mereka juga harus pergi ke kebun atau tempat lainnya guna mencari bahanbahan makanan untuk campur nasi. Mereka untuk mendapatkan bahan tersebut kadang berjalan cukup jauh dengan jarak berkilo-kilo meter dari rumah (Nengsih, Wawancara tanggal 25 Agustus 2004). Kekurangan gizi dan penyakit busung lapar terjadi di manamana, dan banyak orang yang mati kelaparan Berdasarkan informasi To'I dan Halim, yang banyak menderita adalah kaum perempuan dan anak - anak. Mereka sering menemukan mayat perempuan dan anak-anak dipinggirpinggir jalan, di parit-parit maupun yang sedang sekarat meregang nyawa di daerah perkebunan terutama di kebunkebun singkong seperti di daerah Ciambar. Selain itu di desa-desa sekitar wilayah Cicurug banyak orang yang menjadi siring terutama datang dari daerah kontrak, diantaranya kontrak Parakansalak. Seperti halnya di Desa Cipanengah, banyak siring yang datang misalnya dari Parakansalak, Cidahu, dan Jabon. Karena di desa tersebut juga sedang dilanda kemiskinan, maka siring yang datang disiringkan lagi ke desa-desa sekitarnya seperti ke Kompa, Cibodas, Pondok Kaso Tengah. Tidak jarang siring-siring tadi oleh penduduk Desa 
Cipanengah yang sekiranya mereka akan mati dikuburkan secara hidup-hidup, seperti yang terjadi di Kalapa Carang, Cipanengah, maupun di Legok Gedud.

Selain susah makanan sehingga tidak bisa makan secara normal, masyarakat sangat susah sandang. Mereka tidak bisa memakai pakaian layak. Seperti yang disampaikan oleh Engkom, Nengsih, dan Uho, mereka tidak lagi memakai samping sebagai penutup auratnya yang dibuat dari kain. Samping yang mereka pakai yaitu terbuat dari karet, sehingga kalau siang hari terasa sangat panas sekali dan jika dipakai berjalan akan terdengar berisik. Sedangkan untuk laki-laki pakaiannya terutama kolor sebagai penutup auratnya, terbuat dari urung (sarung) kasur yang dibuka kemudian dijahit, dan kalau dipakai terasa gatal-gatal karena dalam kain tersebut terdapat banyak tumbila (kutu) sehingga banyak timbul penyakit budug atau koreng (Engkom, wawancara tanggal 7 Juli 2004).

Program wajib serah padi oleh Pemerintah Pendudukan Jepang yang telah mengakibatkan kemiskinan secara sistematis, hal ini menimbulkan kegelisahan di kalangan masyarakat. Penderitaan yang telah melampaui batas kemanusiaan melahirkan benih-benih kebencian, dan kemarahan yang menggelora di dalam dada masyarakat.

\section{c. Romusha}

Selain kemiskinan dan kemelaratan yang sangat hebat akibat diterapkannya wajib serah padi, hal yang sangat mengerikan bagi kehidupan masyarakat Sukabumi saat pendudukan Jepang adalah adalah romusha. Kata romusha itu sendiri secara harpiah berarti seorang pekerja yang melakukan pekerjaan sebagai buruh kasar. Dalam konteks Sejarah Indonesia, istilah ini mempunyai pengertian khusus mengingat pengalaman pahit yang dialami rakyat dibawah pemerintahan Pendudukan Jepang yang kejam. Bagi orang
Indonesia, romusha adalah buruh kuli yang dimobilisasi bagi pekerjaan kasar di daerah kekuasaan militer Jepang.

Pada umumnya romusha adalah para petani biasa, yang di luar kehendaknya mereka diperintahkan oleh Pemerintah Pendudukan Jepang supaya bekerja pada proyek-proyek pembangunan terutama yang mendukung pada program perangnya (Kurasawa, 1993: 123).

Pengertian romusha mengalami pergeseran dari kepentingan ekonomi menjadi kepentingan perang. Pada awalnya mereka secara umum dipekerjakan oleh perusahaan-perusahaan swasta bagi pekerjaan produktif, dan juga dianggap kurang lebih sama sebagai buruh tetap, kemudian berubah menjadi kepentingan perang dan tenaganya mulai dipekerjakan secara langsung oleh Jepang untuk mebangun fasilitas pertahanan dan mereka dianggap sebagai buruh kuli paksaan (Kurasawa, 1993:123-126).

Para romusha dipaksa bekerja tidak hanya di daerah yang berdekatan dengan tempat tinggalnya, tetapi oleh Jepang diangkut ke mana saja ke daerah yang menuntut adanya tenaga kerja. Salah satu daerah yang menjadi tujuan bagi pengiriman romusha oleh pemerintahan pendudukan Jepang adalah daerah Banten. Ke daerah tersebut oleh pemerintah pendudukan Jepang banyak dikirimkan tenaga romusha diantaranya dari daerah Sukabumi. Banten saat itu merupakan salah satu daerah yang terbelakang di Jawa, dan di sana Jepang menemukan kemungkinan besar bagi pengembangan ekonominya. Perhatian Pemerintahan Pendudukan Jepang diberikan pada pembangunan wilayah Selatan keresidenan ini. Beberapa proyek berskala besar dibangun, dan proyekproyek tersebut membutuhkan banyak tenaga kerja. Salah satu proyek diantaranya adalah pembangunan jalur kereta api antara Saketi dan Bayah sepanjang $\quad 150 \quad$ kilometer, 
menghubungkan jalur kereta api yang sudah ada antara Labuhan dan Jakarta dengan wilayah pantai selatan keresidenan tersebut dimana terdapat deposit tambang (Kurasawa, 1993:145).

Menurut Tan Malaka (1948:147) yang pada saat itu bekerja sebagai salah satu pengawas romusha, bahwa proyek di Banten diselesaikan sampai dengan bulan April 1944, dimana sejumlah besar tenaga kerja yang dimobilisasikan, dikabarkan sekitar 10.000 orang meninggal dunia akibat kerja keras. Ia pun membandingkan pembangunan di Banten dengan pembangunan jalan kereta api dan jalan raya antara AnyerBanyuwangi pada masa pemerintahan kolonial Belanda, ketika sejumlah besar kuli paksaan dimobilisasikan dan ribuan orang diantaranya meninggal dunia.

Di samping membangun jalan kereta api antara Saketi dan Bayah, disana juga terdapat proyek pembangunan jalan raya Selatan Banten antara Malimping dan Bayah serta pembangunan lapangan udara di Rumpin dimana tenaga kerjanya banyak yang berasal dari Sukabumi. Kemudian bersamaan dengan pembangunan jalan, juga dilaksanakan pembangunan pertambangan batubara di Selatan Banten yaitu di Bayah yang terletak daerah kabupaten Lebak (Malaka, 2000: 148).

Pada tahun 1944 sekitar 16.000 romusha bekerja di Bayah. Kemudian sekitar 11 Kilometer dari Bayah terdapat tambang emas Cikotok yang telah dieksploitasi sejak zaman Belanda. Dari pertambangan itu, pada zaman Jepang selain Emas juga dieksploitasi timah dan seng dengan menggunakan sekitar 1.200 romusha setiap harinya. Diantara romusha yang bekerja di sana berasal dari daerah Sukabumi yang dibawa lewat jalur Sukabumi Selatan, yaitu melalui jalan Pelabuhan Ratu, Cisolok dan Cibareno kemudian masuk ke wilayah Bayah.

Daerah Banten saat itu menjadi pusat kerja romusha terpenting, sehingga puluhan ribu romusha telah dikirim dengan menggunakan kereta api ke daerah itu secara bergiliran dengan masa kontrak selama 3 bulan. Sebagaimana di ceritakan oleh para informan mantan romusha dari Sukabumi yang bekerja di Rumpin Banten, para romusha dari Sukabumi dikirimkan ke Cikoleang Rumpin dengan menggunakan kereta api sebanyak 16 gerbong dengan muatan kurang lebih 3000 orang. Para romusha diambil dari setiap stasiun kereta api sejak dari stasiun kota Sukabumi kemudian stasiun Cibadak, Parungkuda serta stasiun Cicurug, setelah terlebih dahulu dikumpulkan oleh petugas di wilayahnya masing-masing. Kemudian para romusha dari Sukabumi itu dibawa ke Banten. Perjalanan kereta api terus menerus tidak pernah berhenti baik di Bogor maupun Manggarai menuju ke Banten lewat Tanah Abang kemudian turun di Pos Cisawu. Setelah turun dari Pos Cisawu, para romusha berjalan selama satu setengah jam untuk mencapai ke Cikoleang Rumpin atau ke tempat dimana para romusha akan bekerja (Oci, wawancara tanggal 25 Maret 2004)

Para romusha yang dikirim ke Rumpin atau tempat lainnya di Banten berasal dari desa-desa, mereka umumnya adalah para petani atau penduduk desa yang tidak mempunyai pekerjaan. Seperti yang diungkapkan oleh Maemunah (wawancara tanggal 30 Agustus 2004) salah seorang isteri romusha yang berasal dari kampung Tapos desa Cibodas, bahwa suaminya menerima tawaran jadi romusha karena dia tidak mempunyai pekerjaan dengan harapan dapat upah untuk menunjang kelangsungan hidup yang saat itu sedang dalam keadaan susah. Pada umumnya mereka ditunjuk langsung oleh kepala desa untuk mewakili desanya diambil dari masingmasing kampung yang berada di desa tersebut. Untuk daerah Sukabumi masing-masing kampung diwakili oleh lima orang. Salah satu contohnya Desa 
Cibodas di wilayah Cicurug yang mempunyai empat kampung dan masingmasing kampung lima orang romusha, maka Kepala Desa Cibodas mengirimkan romusha untuk bekerja di Rumpin sebanyak dua puluh orang. Mereka berangkat melalui stasiun Parungkuda (Sam Indit,wawancara tanggal 20 Januari 2003).

Pada saat para suami pergi menjadi romusha, peran kepala keluarga yang waktu itu sedang dibebani oleh penderitaaan ekonomi akibat susahnya bahan makanan, digantikan oleh para isterinya dengan peran ganda, yaitu sebagai seorang ibu rumah tangga, juga sebagai kepala keluarga. Menurut Maemunah dan Nengsih, mereka menggantikan posisi suami yang harus menanggung beban dan tugas untuk menghidupi keluarga selama ditinggal oleh suaminya. Peran ganda kaum perempuan saat itu dimulai dari mengurus anak dan keluarga juga harus bekerja di luar rumah seperti pergi ke sawah, atau ke kebun mencari ubi, pisang, atau yang lainnya untuk bahan makanan. Para wanita juga tidak jarang harus mencangkul tanah atau membetulkan kerusakan-kerusakan rumah seperti membetulkan genteng sendiri dengan cara memanjat pakai tangga ke atas atap rumah. Semua pekerjaan itu dilakukannya dengan harapan jika para suaminya pulang dari romusha akan membawa uang yang banyak untuk menutupi kebutuhan hidup ( Syafe'i, wawancara tanggal 14 Januari 2003).

Tidak sedikit para romusha yang telah sampai di Cikoleang Rumpin Banten, berusaha melarikan diri dari tempat itu. Seperti yang dilakukan oleh para romusha yang berasal dari desa Pondok Kaso Tonggoh, Cibodas Parungkuda Sukabumi diantaranya romusha yang bernama Oci, Syafei, Dawani, Djakaria, San Indit, dan lainnya yang berjumlah empat puluh orang dipimpin oleh Mansur. Mereka melarikan diri dari Cikoleang Rumpin pada pukul dua tengah malam lewat jalan belakang dengan menyusuri Sungai Ciujung dan menyebrang dengan menggunakan rakit/ getek yang kebetulan saat itu mereka temukan. Setelah menyeberang Sungai Ciujung dalam perjalanan ke Sukabumi mereka menginap di Ciampea Bogor (Jahari, wawancara 12 Januari 2003). Adapun lamanya perjalanan antara Cikoleang Rumpin Banten sampai di kampung mereka selama dua hari dua malam perjalanan kaki. Salah seorang isteri mantan romusha yang bernama Nengsih (wawancara 25 Agustus 2004) menceritakan, bahwa ketika suaminya datang pulang dari Rumpin dengan cara melarikan diri, keadaannya sangat menyedihkan, badannya kurus kering, lemas, dan pakaiannya compangcamping seperti orang gila. Apa yang dialami Nengsih dialami juga oleh Maemunah (wawancara tanggal 30 Agustus 2004), saat mendapati suaminya pulang romusha dalam kondisi seperti itu, maka hancurlah harapan yang telah diimpikannya pada saat dia mengantar kepergian suaminya pergi untuk jadi romusha.

Para romusha dari Sukabumi melarikan diri dari Cikoleang Rumpin Banten, karena tidak tahan bekerja yang sangat berat, yaitu melakukan gugur gunung dengan cara menebangi pohon karet di hutan dan membuat landasan kapal udara, juga karena di tempat romusha sangat kekurangan makanan. Nasi yang disediakan untuk para romusha tidak cukup, bahkan nasi yang ada juga banyak pasirnya. Pembagian jatah makan dilakukan dengan cara antri. Menurut mereka apa yang terjadi di Cikoleang Rumpin bertentangan dengan apa yang dikatakan oleh komandan regu mereka saat direkrut jadi romusha.

Pada saat ditawari jadi romusha, mereka harus membawa bantal dan tikar untuk tidur. Kemudian juga harus bawa piring, sendok, dan garpu serta pisau. Alat-alat itu akan digunakan untuk 
peralatan makan, karena di tempat kerja akan diberi makanan berupa nasi dengan daging sehingga memerlukan garpu dan pisau untuk memotong-motong daging pada saat mereka makan. Sementara itu dalam kenyataannya di tempat romusha jangankan makan dengan daging, nasi yang ada juga penuh dengan bubuk genteng, paling bagus makan rebus ubi. Selain itu di tempat romusha sangat kekurangan air, mereka kehausan, juga tidak ada sarana MCK, sehingga dengan mudah para romusha diserang penyakit (Jahari, wawancara tanggal 12 Januari 2003 ).

Menurut beberapa orang mantan romusha mengatakan bahwa kondisi yang lebih menyedihkan justru menunggu mereka yang beruntung tetap hidup dalam perjalanan menuju tempat tujuan mereka. Kebanyakan lokasi proyek kerja romusha di tempat di tempat yang jauh, kadang-kadang mereka menempuhnya dengan jalan kaki dengan waktu tempuh sampai berjam-jam. Di beberapa tempat tersebut penyakit menular merupakan suatu hal yang biasa ditemui, selain itu juga tidak tersedia air untuk mandi. Romusha ditempatkan di barak-barak sederhana terbuat dari bambu dan kayu serta sebagian besar romusha di jejalkan dalam satu ruang kecil. Makanan yang disediakan untuk romusha sangat buruk, jumlahnya sangat kurang dan mutunya sangat rendah daripada makanan yang biasa mereka makan dirumahnya. Karena kurangnya makanan yang diberikan di tempat romusha, telah menimbulkan kelaparan dan penyakit sehingga banyak orang yang tidak kuat dan akhirnya meninggal.

Bagi masyarakat Sukabumi, hidup di bawah kekuasaan Jepang merupakan mimpi buruk yang tidak pernah akan hilang dari ingatan. Jepang tidak hanya menyebabkan hilangnya nyawa secara besar-besaran, tetapi juga menganggu kegiatan ekonomi yang normal di pedesaan. Penurunan produksi secara serius pada jaman Jepang sebagian disebabkan oleh kurangnya tenaga kerja akibat penekanan romusha. Bagi para penduduk desa, Jepang bagai vampir yang terus menerus mengisap darah masyarakat. Rakyat terus menerus cemas karena mereka selalu berpikir siapa kirakira yang akan menjadi korban kebijakan Jepang berikutnya. Perasaan itu terus menghantui penduduk pedesaan di Sukabumi terutama bagi kaum perempuan, karena mereka akan merasakan beban berat menanggung penderitaan terutama jika para suami mereka yang jadi romusha tidak kembali lagi ke rumah karena meninggal di tempat romusha atau saat melarikan diri dari romusha, mereka harus mengurus anak-anak yang telah jadi yatim dan harus membesarkannya tanpa suami yang biasa jadi tumpuan keluarga dalam keadaan ekonomi yang sangat miskin.

Hal itu merupakan salah satu faktor yang kemudian membangkitkan kebencian dan semangat perlawanan terhadap Jepang, terutama saat menjelang revolusi.

\section{PENUTUP}

Dari uraian di atas dapat disimpulkan bahwa kedatangan Tentara Jepang ke Sukabumi adalah untuk mengambilalih dan menguasai daerahdaerah perkebunan yang ada didaerah itu. Daerah perkebunan di Sukabumi dijadikan sebagai sumber ekonomi untuk menjalankan politik ekonomi perangnya.

Akibat kebijakan Pemerintah Pendudukan Jepang di Sukabumi yang menggunakan pengaruh dari tokoh-tokoh Agama dalam propagandanya, program Wajib Serah Padi dan Romusha telah mengakibatkan bencana kemanusiaan yang ditimbulkan oleh kesengsaraan luar biasa yang dialami penduduk Sukabumi terutama di daerah wilayah Cicurug. Penderitaan yang dialami masyarakat saat itu adalah berupa kelaparan yang terjadi dimana mana dan menimbulkan angka kematian yang cukup tinggi. Makan nasi diganti dengan makanan lain 
berupa bekatul, umbi-umbian dan lainnya yang biasa dimakan binatang.

Peristiwa kemanusiaan dalam Sejarah Pendudukan Jepang di Sukabumi merupakan pelajaran tersendiri bagi bangsa Indonesia, bahwa hidup di bawah kekuasaan bangsa lain akan dan selalu menimbulkan kesengsaraan.

\section{DAFTAR SUMBER}

\section{Buku}

Anderson, Benedict O'Gorman. 1988.

Java in A Time of Revolution, Occuption and Residentence 19421946 Revolusi Pemoeda; Pendudukan Jepang dan Perlawanan di Jawa 1944-1946. Diterjemahkan oleh Jiman Rumbo Jakarta: Sinar Harapan.

Benda, Harry J. 1958.

The Crescent and the Rising Sun: Indonesian Islam under the Japanese Occupation 1942- 1945. The Hague van Hoeve.

Haasse, Hella S. 1994.

Heren van de Thee. Den Haag: Callenfels.

Iskandar, Muhammad. 2000.

Peranan Elit Agama Pada Masa Revolusi Kemerdekaan Indonesia. Jakarta: Depdiknas.

Jaya, Ruyatna. 2002.

Sejarah Sukabumi. Pemda Kota Sukabumi.

Kanahele, George Sanford. 1967.

The Javanese Occupation of Indonesia: Prelude to Independence. Cornel University.

Kunto, Haryoto. 1984. Wajah Bandoeng Tempo Doeloe. Bandung.

Kurasawa, Aiko. 1993.

Mobilisasi dan Kontrol: Studi tentang Perubahan Sosial di Pedesaan Jawa 1942-145. Alih bahasa oleh Hermawan Sulistyo Jakarta: Gramedia.

Kurasawa, Aiko. 1988.
Pendudukan Jepang dan Perubahan Sosial: Penyerahan Padi Secara Paksa dan Pemberontakan Petani Di Indramayu. Jakarta: Yayasan Obor Indonesia.

Lubis, Nina Herlina. 1998.

Kehidupan Kaum Menak Priangan 1800-1942, Bandung: Pusat Kebudayaan Sunda.

Nagazumi, Akira ( penyunting ). 1988.

Pemberontakan Indonesia Di Masa Pendudukan Jepang. Jakarta: Yayasan Obor Indonesia.

Notosusanto, Nugroho. 1979.

Tentara PETA Pada Jaman Pendudukan Jepang di Indonesia. Jakarta: Gramedia.

Mawardi, A. Mukhtar. 1985.

Haji Ahmad Sanusi Hidup dan Perjuangannya. Skripsi Sarjana. Jakarta: IAIN Syarif Hidayatullah.

Poesponegoro, Marwati Djoened dan Nugroho Notosusanto.1990.

Sejarah Nasional Indonesia Jilid VI, Jakarta, Balai Pustaka.

Sulasman. 2008.

K.H. Ahmad Sanusi Berjuang Dari Pesantren Hingga Parlemen. Bandung: PUI Press. 2008.

K.H. Ahmad Sanusi Berjuang Dari Pesantren Hingga Parlemen, dalam Ulama Ulama Perintis Biografi Pemikiran dan Keteladanan. Bandung: MUI Kota Bandung.

Tan Malaka. 2000.

Dari Penjara ke Penjara Jilid II, III. Jakarta:Teplok Press.

\section{Surat Kabar}

Asia Raja, tanggal 28 Mei 1942.

Soeara Moeslimin Indonesia Vol. II No. 17 tanggal 1 September 1944.

Soeara Asia, bulan April 1944.

\section{Informan}

Halim (88 Tahun). Mantan Pedagang Keliling di perkebunan Parakansalak. 
Wawancara. Parakansalak. 10 Mei 2004.

Dadun Abdulqohar (90 Tahun). Mantan Hisbullah. Wawancara. Cibadak. 25 Maret 1999.

Nining (94 Tahun) Mantan Pemetik Teh Perkebunan Parakansalak, wawancara Parakansalak. 14 Pebruari 2004.

Engkom (85 Tahun). Isteri Romusha. Wawancara. Sukabumi. 7 Juli 2004.

Sanukri (87 Tahun). Mantan Hizbullah. Wawancara. Sukabumi. 20 Juli 2004.

Nengsih (80 Tahun). Isteri Romusha. Wawancara. Sukabumi. 1 Juli 2005.

Oci (88 Tahun). Mantan Romusha. Wawancara. Sukabumi. 20 Mei 2004.

Maemunah (85 Tahun). Isteri Romusha. Wawancara. Sukabumi. 30 Agustus 2004.

Jahari, ( 87 Tahun). Mantan Romusha. Wawancara. Sukabumi. 12 Januari 2003.

Sam Indit (88 Tahun). Mantan Romusha. Wawancara. Sukabumi. 20 Januari 2003.

Syafe'i ( 85 Tahun). Mantan Romusha. Wawancara. Sukabumi. 14 Januari 2003. 
